\title{
Det tavse sprog
}

\author{
af Bruno Ingemann
}

Artiklen fokuserer på avisens layout - eller mere precist: På avisens visuelle udtryk. Tekst ses forst som et billede. Teksten er visuel og dermed indgair den sammen med fotografier og tegninger i et samlet hele, der organiseres som en billede. Det er dette helhedsbillede artiklen prover at forankre teoretisk og metodisk med henblik på at vise, hiordan det er muligt at analysere avisens visuelle udtryk.

\section{Den visuelle analyses tre niveauer}

En avis er komplicerct at analysere. Der er så utrolig mange dele $i$ avisen, som tilsammen skaber den samlede potentielle betydning. For overhovedet at fa ryddet lidt op i dette ordnede kaos er det nodvendigt at fä formuleret en interessant problemstilling, som det er hensigten at analysere frem af materialet. ${ }^{1}$

Den konkrete analyse kan man gribe an på tre niveauer: ${ }^{2}$

- Det øverste niveau: Helhedsbilledet; Kompositon; Stil.

- Det mellemste niveau: Billedet; ${ }^{3}$ Overskriften; $^{2}$ Billedteksten; Manchetten.

- Det nederste niveau: Teksten; struktur; Argumentation; Stil. ${ }^{4}$

Hvad der betinger disse niveauer er, at de folger den måde, som den almindelige laser opfatter og laser avisen. Det betyder ikke, at laseren er sig denne proces bevidst, nej det er meget ubevidste processer, og de betydningspotentialer, som den konkrete avis har, bliver ikke nødvendigvis opfattet sådan men kan sagtens vendes fuldstandig på hovedet.

Man kan se avisens layout som en i-side-sattelse. Det er ligesom iscenesattelsen på teatret. De roller, der i-side-sattes på avisens scene, er en række losdele eller en rakke aktører, der placeres inden for avissidens ramme og som gennem i-side-sattelsen giver mulighed for at skabe og konstruere en sammenhængede virkelighed og en sammenhangende fortalling.
Jeg vil her udelukkende fokusere på Det overste niveau: Helhedsbilledet. Det er her, fotografier, tegninger, nyhedsgrafik indgår som visuelle elementer $i$ helheden. Men det indebærer samtidig, at overskrifter og tekst betragtes, som de visuelle elementer de også er.

\section{Mondrian}

Du kender det typiske Mondrian-billede: Det består afens tykke lodrette og vandrette sorte streger, som inddeler den hvide flade i en rakke rektangler og kvadrater. De eneste farver, han bruger, er de rene farver: Rød, gul og blä. For Mondrian var dette meget begransede udtryksspektrum et udtryk for den mekaniske og tekniske orden og for menneskelig konstruktion. Men det var også et forsog på at udtrykke den nye ånd i logik, videnskab og religion og dermed et udtryk for en klar relation til det universelle.

Năr man ser på en moderne avis, så ligner den på mange måde et Mondrian-billede. Den hvide side er fyldt godt op. Der er masser af gra tekstspalter. Der er mange farvede felter, og siden er ikke inddelt med sorte streger men derimod med hvide streger, der adskiller spalterne og de cnkelte artikler. Man kan se det som et udtryk for den mekaniske og tekniske orden og for menneskelig konstruktion. $P_{a}^{\circ}$ det rent tekniske niveau kan det forekomme naturligt, fordi teksten nu engang er i spalter og fordi fotografier nu engang er rektangulere osv. Men det cret valg og ikke en tilfeldighed. 


\section{POLITIKEN}

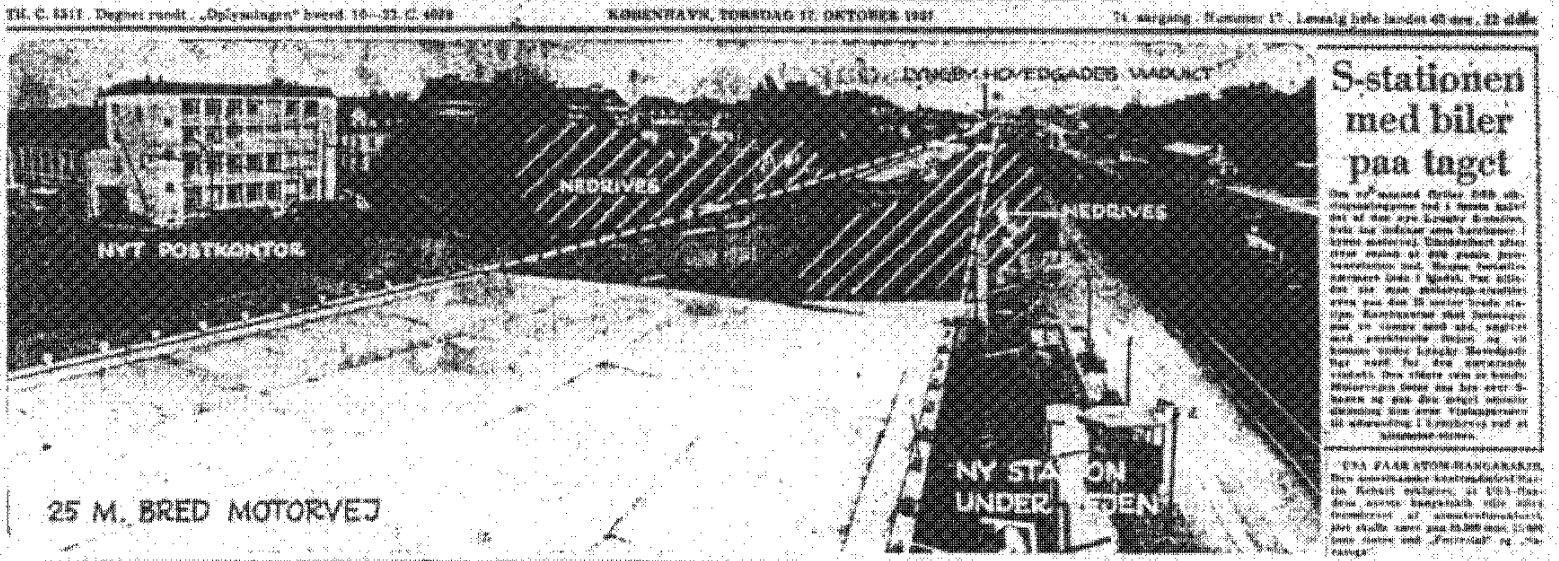

\section{Syrien-krisen skarpet med drastisk Sovjet-beskyldning}

Iunden wad Flere og flere na a til pas frigeren sengs med influenza

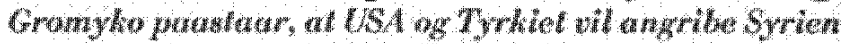

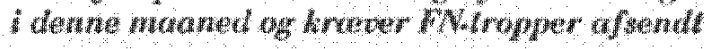

.Sovjet rede til at deltage med sine styrker

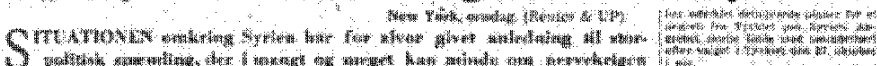

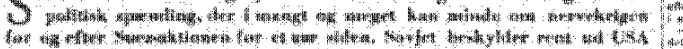

称

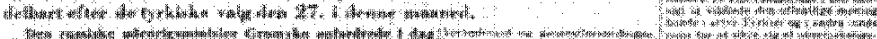

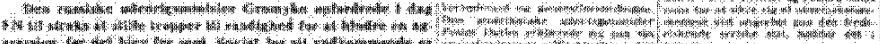

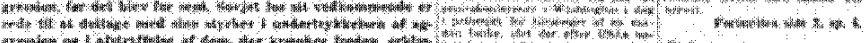

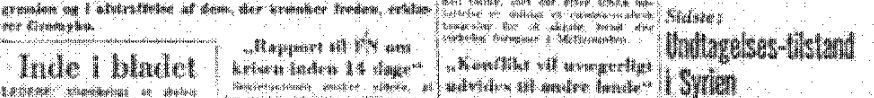

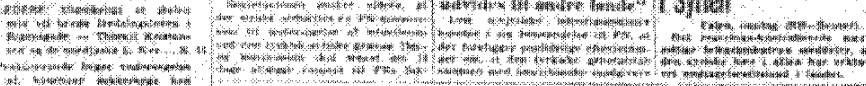

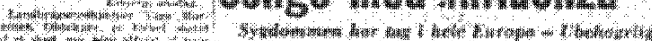

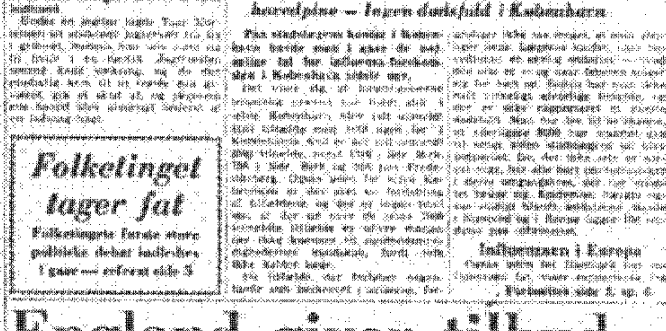
$=-$ Brint-bombens enorme England giver tilbud om landbrugs-ordning

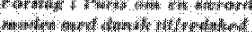

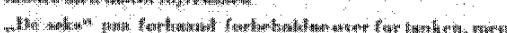

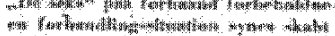

\section{$\pm=-$ energi til el-kraft}

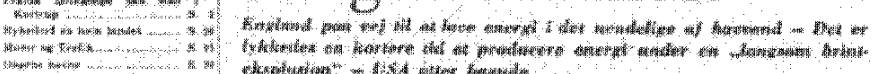

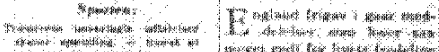

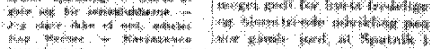

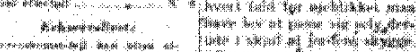

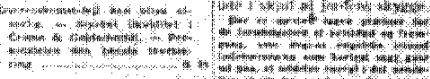

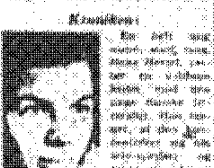

wim

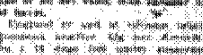

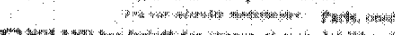

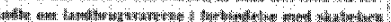

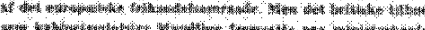

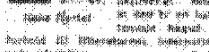

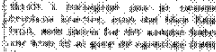

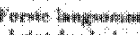

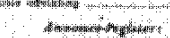

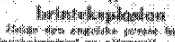

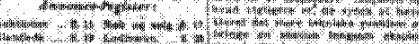

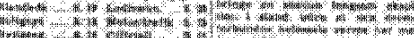
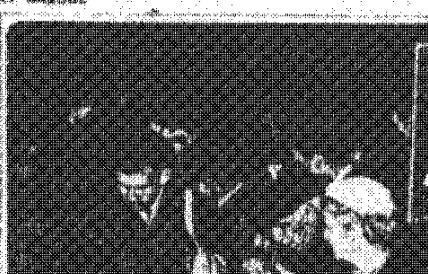

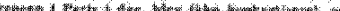

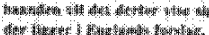

\section{at} 2wo 72 st
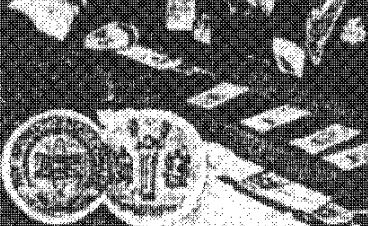

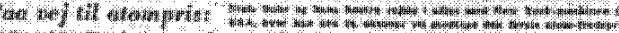

ines:
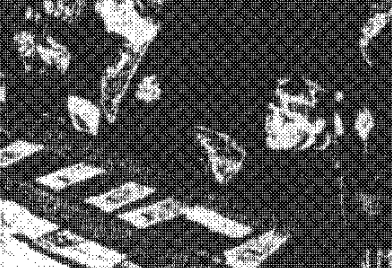

Tit:
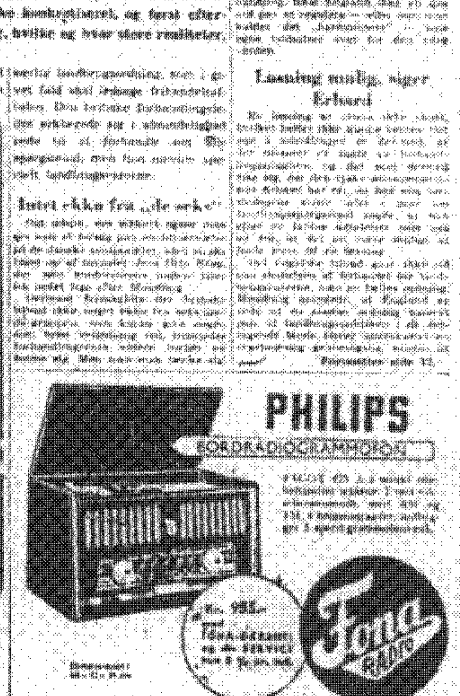

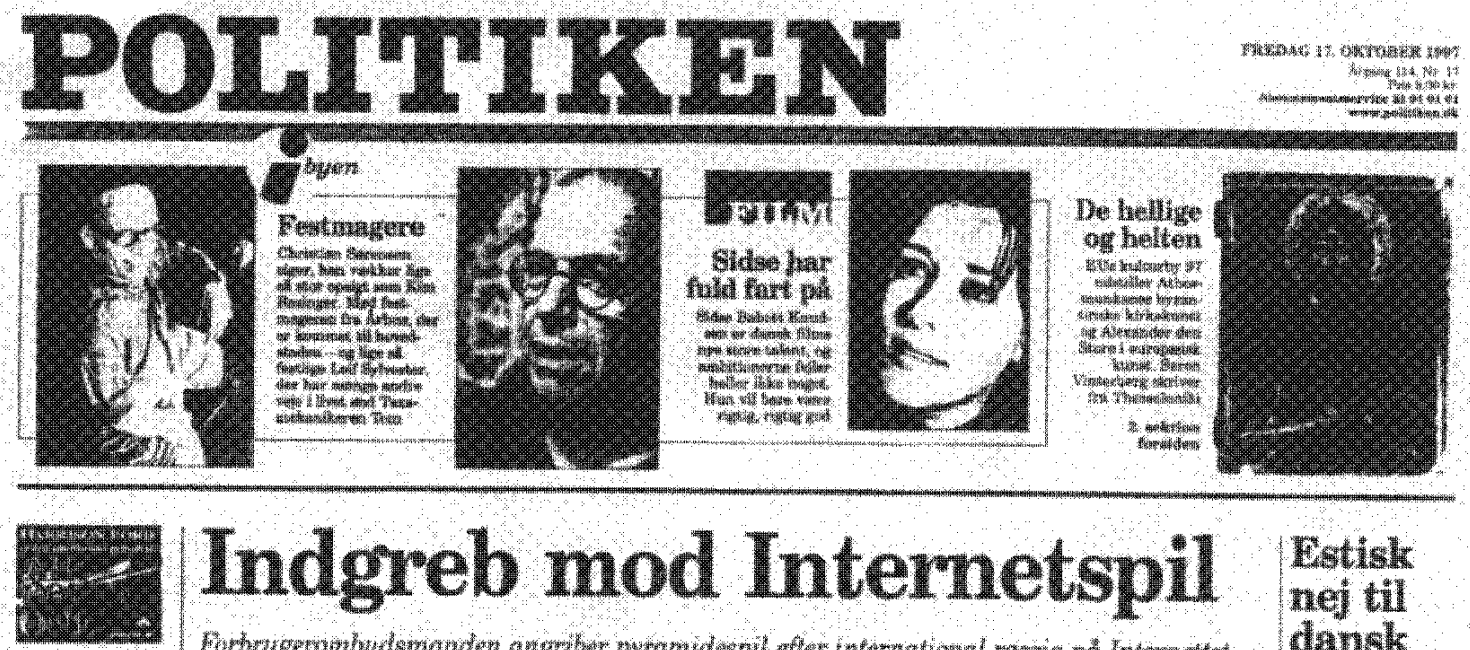

\section{Indgreb mod Internetspil}

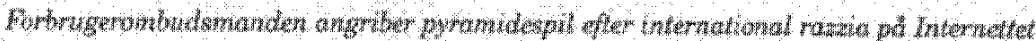

\begin{tabular}{|c|}
\hline 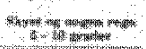 \\
\hline
\end{tabular}

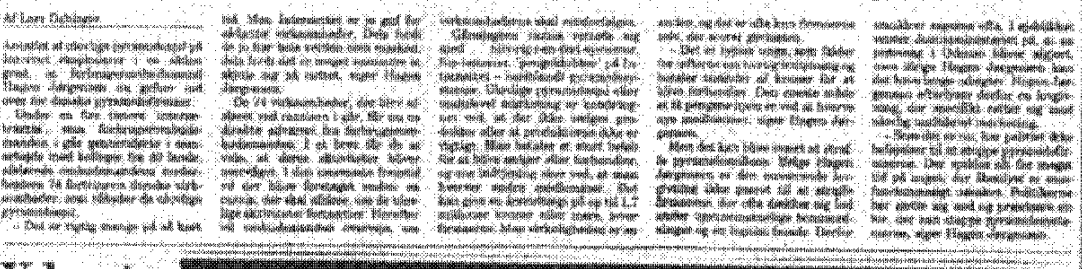

Astisk (1) clansk

W

tor

Tis

is

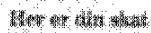

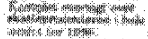

1) 1 is

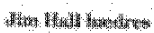

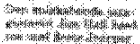

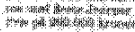

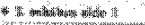

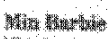

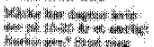

(196)

1)

A

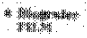

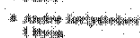

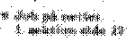

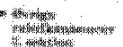

…

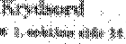

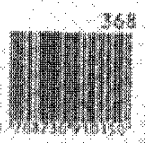

\section{Yderste}

hojre

star til

storsejr

at ow whw

A

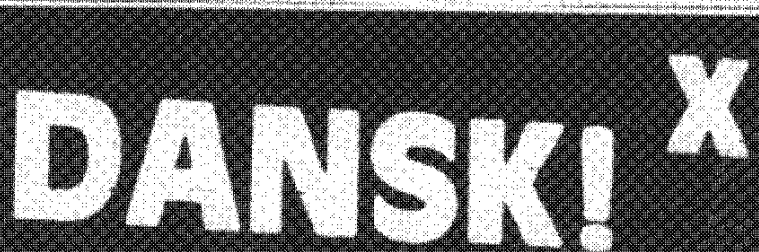

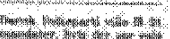

(15).

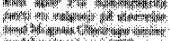

and

1rits

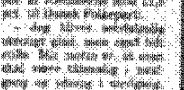

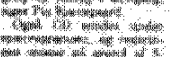

fortint

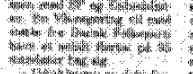

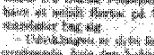

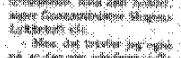

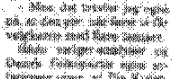

1.m.

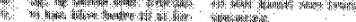

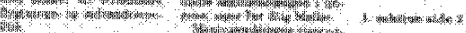

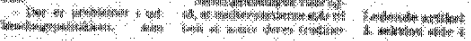
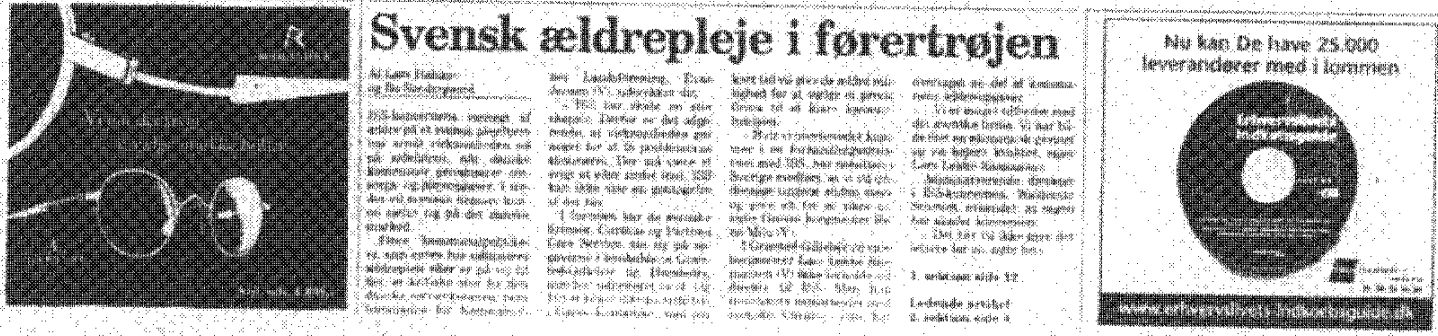


\section{Komposition - se siden som et billede}

Vi kan prove at se på to forsider af Politiken. ${ }^{5}$ Det ene er fra 57 og det andet er fra' 97 . Hvordan adskiller de sig fra hinanden?

57forsiden indeholder 9 historier eller mindre tekststumper, som henviser til artikler inde i avisen, og hver enkelt del bugter sig ud og ind imellem de andre artikler. Der bruges mindst $14-15$ forskellige skriftyper eller storrelser, og det kaotiske indtryk understreges af at nogle overskrifter holder fast forkant, mens andre er centrerede. Der er to store visuelle elementer, som holder lidt styr på de flydende dele, og det cr de to fotografier. Den ene i toppen og den anden $i$ bunden af siden. Fotografierne er med til visuelt at prioritere hver deres delhistorie. Men ingen af fotografieme er sarligt klare eller tydelige. Det øverste en en slags informationsgrafik, hvor der er pategnet en planlagt motorvej ved Lyngbyvej, og det nederste fotografi viser Niels Bohr på vej til at modtage en atomfredspris i New York. Nederst til højre på siden er der en annonce for Fona. Denne annonces restetik ligner avisens med mange smá dele der glide ind $o g$ ud ad hinanden.

Det konnotative niveau: Det astetisk udtryk virker kaotisk og rodet. For at kunne sige noget om det astetiske udtryk kan man f.eks. arbejde med at opstille visuelle differentialer (Ingemann 1991:53-61). Visuelle differentialer er ikke udtryk for normative krav eller kvaliteter, men de konstrueres i relation til det givne materiale for at kunne skabe en forståelse for, hvad der lagges vagt på, og hvad der cr udeladt i den visuelle organisering.

Når det galder vurderingen af Helhedsbilledet i 57-forsiden, kan man f.eks. opstille følgende visuelle differentiale:

$\begin{array}{rll}\begin{array}{r}\text { Hoj orden } \\ \text { velordnet }\end{array} & \ldots \ldots \ldots \ldots \ldots & \begin{array}{l}\text { Lav orden } \\ \text { kaotisk }\end{array} \\ \text { geometrisk } & \ldots \ldots \ldots \ldots \ldots . . & \text { amorf } \\ \text { formel } & \ldots \ldots \ldots \ldots \ldots & \text { tilfaldig } \\ \text { modul } & \ldots \ldots \ldots \ldots \ldots . . & \text { uregelmassig } \\ \text { systematisk } & \ldots \ldots \ldots \ldots \ldots & \text { sporadisk }\end{array}$

57-forsiden kan siges at udgøre en helhed med lav orden. Den virker ternmelig kaotisk, den er amorf gennem de mange dele, der flyder ind over hinanden, og som er lagt oven pá hinanden som sten i et stengærde. Den lave orden giver et astetisk udtryk, som virker tilfaldigt, og som i hvert fald ikke er en prioritering af losdelene i virkelighedskonstruktionen, og dermed er der ikke noget, som gores serligt fremtrædende. Man kan omvendt opfatte det som positivt på den måde, at avisen lagger løsdelene frem til laserens egen vurdering. Avisen gor ikke noget for at prioritere én del frem for en anden. Man kan derfor sige, at layouten ikke styrer læseren ved at etablere et visuelt hierarki. Tilfaldigheden kommer også til udtryk gennem det store antal forskellige skriftsnit, der er af forskellig storrelse og har en skiftende placering.

97-forsiden ser åbenbart helt forskelligt ud fra 57 forsiden På 97-forsiden bruges der farve, mens 57 forsiden var sort/hvid. Den indeholder 4 historier og en spalte til venstre med 4 henvisninger til historier inde $i$ avisen og 4 henvisninger $i$ toppen af avissiden. Hver enkelt artikel er placeret som en afgranset blok, der er brugt 4 forskellige skrifttyper og størrelser og alle overskrifter holder fast forkant. Der er en rekke mindre sammenhangende fotografier i toppen af siden, og så er det dominerende fotografi, som er vavet tat sammen med selve artiklen og med en informationsgrafik. Det dominerende fotografi er så enkelt og klart, at det næsten fortæller historien i sig selv, men det er tæet understottet af overskriften til artiklen. Nederst på siden er der to annoncer, som er meget enkle og klare med fă elementer, der cr tydeligt prioriteret i forhold til hinanden.

Det konnotative niveau: 97-forsiden kan siges at udgøre en helhed med høj orden. Den cr velordnet, folger et klart modul og er formel og systematisk. De enkelte dele på siden er vagtet klart og tydeligt i forhold til hinanden. De mange indgange til avisen er velordnede og gør det meget nemt for laeseren at orientere sig. Det funktionellc aspekt er her vagtet meget hajt.

Denne analys ${ }^{6}$ kunne nemt fore frem til en normativ vurdering: At det dog er gået fremad i stil og smag, når det galder det visuelle udtryk. Men sådan kan man ikke se det. 57-forsiden har mange kvaliteter netop i kraft af det bløde og organiske, ligesom 97-har sine kvaliteter. Men netop ved at modstille to forskellige forsider giver det mulighed for at sige mere om dem begge og betone de indbyrdes forskelle samt de kvaliteter, de hver især har.

\section{Struktur - det formelle}

Avissiden er en rumlig komposition, hor alle delene kan ses ud fra to paradigmer: Top/bund og centrum/margen. 


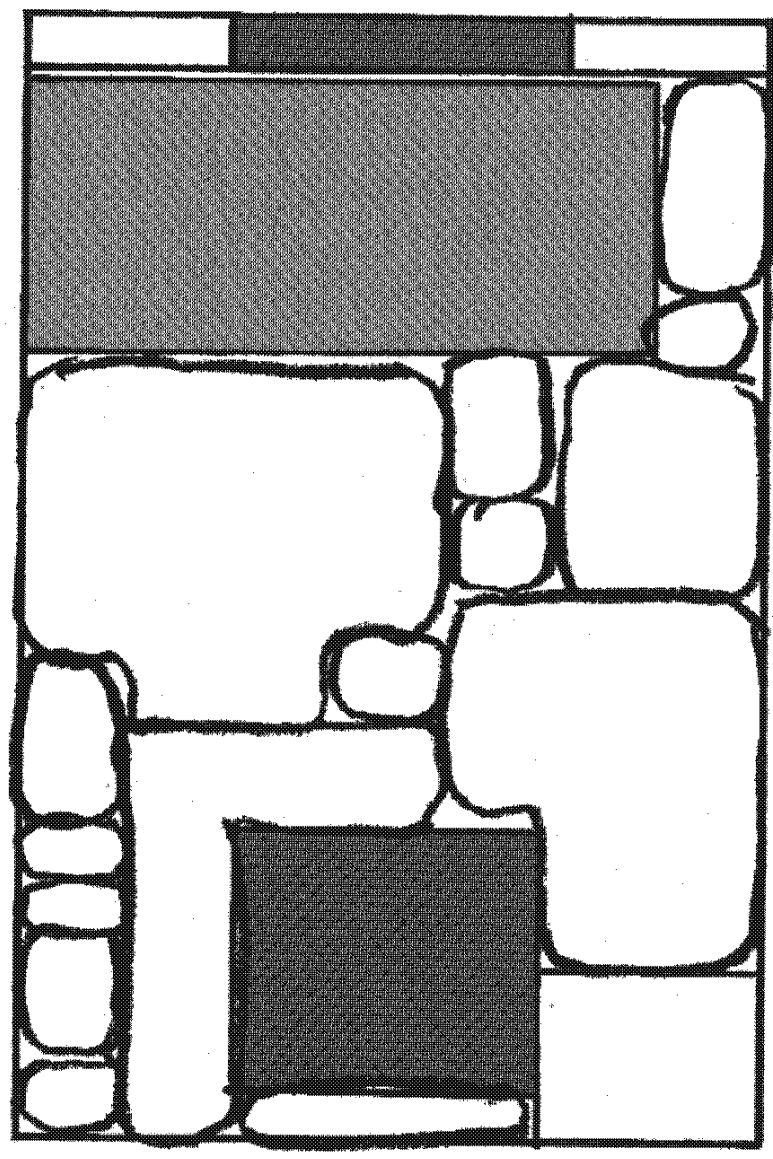

3- 57-forsiden. Komponeret efter et princip som man kunne kalde stengerdetr. De enkelte dele er lagti sten der bygger et gerde op som er helt fyldt ud.

Top/bund-paradigmet er centralt i avisen. Som læsere ser vi ikke lige opmarksomt på den nederste del af siden som på den øverste del. Gennem vores socialisering som avislæesere har vi lært, at det der stăr i toppen er vigtigere end det, der står i bunden. Det har også en praktisk årsag. Năr det gælder omnibusaviser så ligger de foldet på midten når vi ser dem i kiosken, og derfor må den øverste del af avisens forside tankes, som det laseren forst ser.

57 -forsiden hånterer top/bund zonerne ved at toppen dels er avisens hoved og et stort fotografi placeret lige under. For at trække laserens opmærksom nod mod bunden er det andet fotografi placeret her.

97-forsiden placerer et storre logo i toppen sammen med fire mindre billeder, der skal trakke laserens opmarksomhed ind $i$ avisen som appetitvakkerc. Her valger man at vakke laserens opmarksomhed med det store fotografi, som bliver foldet, så man ikke kan se det helt, năr avisen ligger i kio-

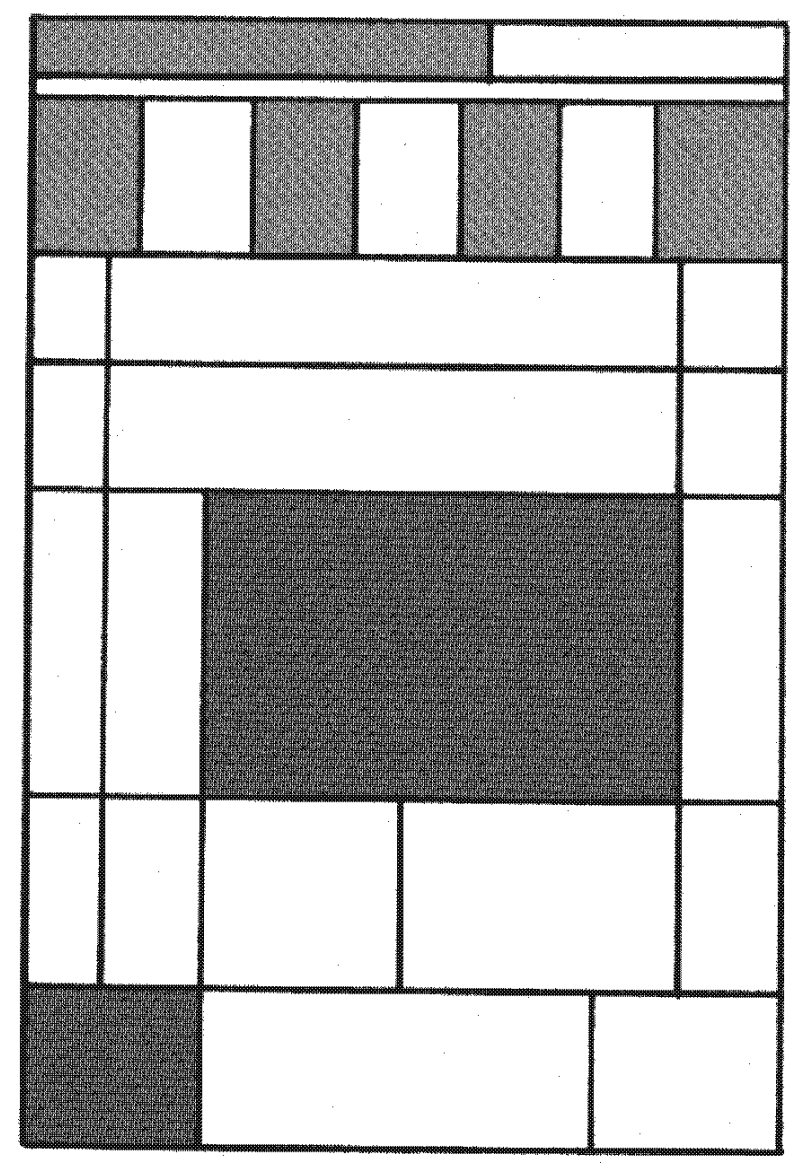

4. 97-fosiden er komponeret meget stramt som et maleri af Piet Mondrian. Flare Lodrette og vandrette tinier deler siden op i mindre dele. Visuelle forskelle fremhever enkelldele.

sken. Det er altså for at vakke nysgerrighed overfor det foto, man ikke rigtigt kan se.

Man kan have den hypotese, at hyis billeder placeres i toppen af siden (eller af den enkelte artikel), så viser det, at det ideologiske i budskabet kommunikeres visuelt og at teksten så tjener til underbygge billedet. Og omvendt hvis billedet er placeret nederst på siden eller i artiklen, så er det teksten, der bxrer det ideale cller ideologiske, mens billedet er forklarende $0 g$ underbyggende.

I artiklen om Dansk Folkepartis store fremgang: er fotografiet af Pia Kjarsgărd placeret i toppen af artiklen som den ideologiske fremtradende del, mens teksten og den forklarende nyhedsgrafik or placeret $i$ bunden som specifik information.

Centrum/margen-paradigmet er brugt meget aktivt på 97-forsiden. Man kan se Dansk Folkcpartihistorien og det iøjnefaldende billede som sidens centrum. De øvrige elementer kan dermed betrag. tes som placeret i sidens margener. Gennem dette starke centrum fremhaves og fokuseres opmark- 
somheden på dette element som meget betydningsfuldt og det, hvorom de ovrige historier holdes fast. Men selv når centret er fravarende, som det f.eks. er på 57 -forsiden, så afslører det sig gennem sit fravar som det usynlige og fornatede center, hvorom alt bevager sig.

\section{De fire funktioner}

De 40 är imellem de to forsider viser ikke kun forskelle på det udtryksmassige plan. Det fortxller ogsă noget om, at layoutens funktioner har forandret sig.

Brugsfunktionen: Hvad bruges layouten til? For en avis er det vigtigt, at der for leseren skabes en ret fast struktur gennem helc avisen. Laseren skal vide, hvor tv-progammerne findes, hvor kronikken står, hvor udenrigsstoffet befinder sig og hvor man kan finde tegnesericme. Hver enkelt avis skaber sin egen ideolekt, og det er gennem praksis, at læseren bliver fortrolig med den konkrete avis' måde at skabe overblik og orientering ved hjalp af layouten. Det er derfor ret forvirrende, hvis man som Politiken-laser skifter til Jyllands Posten fordi man så skal til at læere en ny idcolekt. Og disse skift giver mange problemer for laeseren, năr han/hun skifter avis for at udnytte et tilbud om et billigt abonnement.

Under brugsfunktionens aspekt ses layouten altsia som den totale organisering af hele avisen og dermed også af de mange forskellige scktioner, som den daglige avis består af. Men brugsfunktionen omfatter også hele ugens aviser, fordi de særlige sektioner om Rejser, Computere, Undervisning osv. er placeret på bestemte dage og dermed er orienteringspunkter for den daglige laser.

For at skabe denne struktur bruger avisen on rakke faste elementer, som fungerer fatisk, dvs. at de skal vare med til at sikre, at laseren moder bestemte dele af avisen med bestemte forventninger. Det kan vare cn bestemt typografi, et bestemt logo eller en placering.

Den podagogiske funktion: Hvordan integreres billeder og tekst? Her kan man tale om to overordnede principper: Det ene er, at billeder fungerer som en øjen-fanger, og at billedet oftest er stort og skal lede ind til artiklen gennem det emotionelle indhold, selvom billeder ikke altid er sarlig tat forbundet med artiklens indhold. Det andet princip $\mathrm{er}$ at billedet indgår som en forklarende del i et txt samspil med teksten. Det findes ofte iden infor- mationsgrafik, der i hojere grad informerer om faktuelle forhold.

I Dansk Folkeparti-historien bruges den predagogiske funktion på flere måde. Dels bruges fotografict og overskriften til at fange ojet, dels til at fortælle historien i sig selv. Artiklens tekst uddyber og forklarer den opinionsundersøgelse, som historien bygger på. De samme oplysninger findes mere detaljeret $i$ den nyhedsgrafik, som vises nederst $i$ højre hjorne. Nyhedsgrafik kan i andre sammenhange vare meget forklarende gennem bekrivelser af steder $o g$ begivenheder $i$ et tidsmassigt og rumligt forlob.

I 57-forsiden er der lavet en slags nyhedsgrafik, som oven på et fotografi viser, hvordan en planlagt motorvej placeres ind i det eksisterende miljo.

Mængden af nyhedsgrafik og kvaliteten af visualiseringerne er øget voldsomt gennem årene, for at den moderne avis kan fungere i samspillet med fjernsynet og spille op til det ved bla. at vare mere forklarende og uddybende omkring begivenheder og deres konsekvenser.

Den estetiske funklion: Hvad udtrykker layouten? Ethvert visuelt udtryk er ogsă astetisk. Man kan ikke satte noget på papir, uden at det siger mere end tekstens og billedets indhold.

Valget af format har en brugsfunktion i forhold til den lassesituation, som avisen er tankt ind i: $\mathrm{Om}$ den f.eks. skal læses i toget eller i stolen derhjenme. Men formatet har også en astetisk funktion. Avisens format signalerer i sig selv noget om avisens karakter. Omnibusaviserne med deres store avisformat. Formiddagsbladene med deres tabloidformat. Og det nye Aktuelt med sit smalle amerikanske avisformat. Information har ét xstetisk udtryk og Politiken har ct andet rstetisk udtryk.

Det visulle udtryk er sammensat af mange forskellige virkemidler:

- tckst: brodtekst, overskrifter, manchetter, rubrikker

- fotografier

- tegninger

- informationsgrafik: diagrammer, kort, piktogrammer

- faktabokse

- fremhavede citater

- annoncer

Overordnet er det visuelle udtryk organiseret ud fra principperne om top/bund og centrum/margen. Derigennem udtrykkes det ideelle og ideologiske og det faktuelt informerende.

Den kontekstuelle funktion: Hvordan påvirkes den 
enkelte del af helheden og omvendt? Man kan tale om en rakke kontekster: Der cr den enkelte artikel og billedet - den intime kontekst. Der er artiklens placering på siden - den lokale kontekst. Der er sidens placering $i$ hele avisen - den interne kontekst. Der er dagens avis placering i ugens forløb-den globale kontekst. Og der er avisens placering i relam tion til de øvrige aviser og andre nyhedsmedierden eksteme kontekst. Og så kunne man tale om avisens relation til læseren-leserens kontekst.

Den enkelte hele avis udger dagens imside-sattelse af dognets begivenheder, meninger og oplem velser. Denne i-side-sattelse kan ses som et udvalg blandt en rekke mulige, hvor det aktuelle mediekredsløb mellem fjernsyn, radio og andre aviser er med til at fokusere opmørksomheden på visse ting og gore andre ting usynlige. Men avisens i-side-sattelse kan også ses som et narrativt forlob, hvor avisen forsoger at skabe en samlet fortalling om verden $i \mathrm{dag}{ }^{7}$ Det er som instruktorens iscenesættelse af et teaterstykke. Men avisens i-side-sættelse bruger det visuelle udtryk for at strukturere lasningen og styre laseren.

Alle disse relationer kan det vare nødvendigt at tagc hensyn til i en analyse, men da det samtidiger uhyre komplekst, må man valge, hvilke relationer der i den konkrete analyse skal fokuseres pa. Placeringen af det slående visuelle element på siden som oftcst vil vare et fotografi - er meget styrende for laseren. Dels som det, der er vigtigt og vaesentligt at lagge mærke til, og dels ved at der gennem billedets indhold fokuseres på en bestemt måde at opfatte billedet på. Den visuelle styring ligger $i$, at det både er synligt - vi kan jo alle se billedet - og usynligt, fordi vi gennem vores lynhurtige afkodning af billedet ikke bevidst lagger marke til dets ideologiske og/eller faktuelle indhold.

\section{Den daglige avis - og strukturen}

De visuelle elementer har for altid forandret den måde, hvorpå aviser prasenterer nyheder. "Aviser er endimensionale," sagde direktøren for den amerikanske avis Orlando Sentinel, William Dunn, "Man kaldte computeren for sbrugervenlig«. Fjernsyn er brugervenlig; aviser har yderst sjaldent varet brugervenlige." (Finberg \& Itule 1990:5).

Man kan sige, at den forståelse er et resultat af en afgørende faktor: Faldet $i$ avisernes oplag og forudsigelser om, at potentielle lacsere vil vare afviscnde over for avisen. Men det er også en følge af den overraskende viden om, hvordan lasere bruger deres daglige avis. Fra journalistens synsvinkel er teksten det vigtigste $i$ avisen. De valger omhyggeligt genre og artiklens struktur, de vinkler deres historie i forhold til nyhedskritcrierne, de bruger den omvendte pyramide og anbringer den vigtigste information i begyndelsen af artiklen og den mindst vigtige information $i$ artiklens slutning. Men laserne er ligeglade. Deres læsestrategi følger ikke artiklens struktur.

Den afgørende pointe er, at lasere ikke er lasere men scannere. Det amerikanske Poynter Institute har lavet eksperimenter, hvor lasernes øjenbevagelser er blevet mâlt med små videokameraer, og disse eksperimenter viser netop, at læserne ikke er lasere men scannere.

Og hvad ser så scanneren? Forst bliver et element »set-pă«. At »se-på« noget betyder, at læserens opmarksomhed stopper et kort stykke tid ved et enkelt element f.eks. en overskrift, et foto eller en stump tekst.

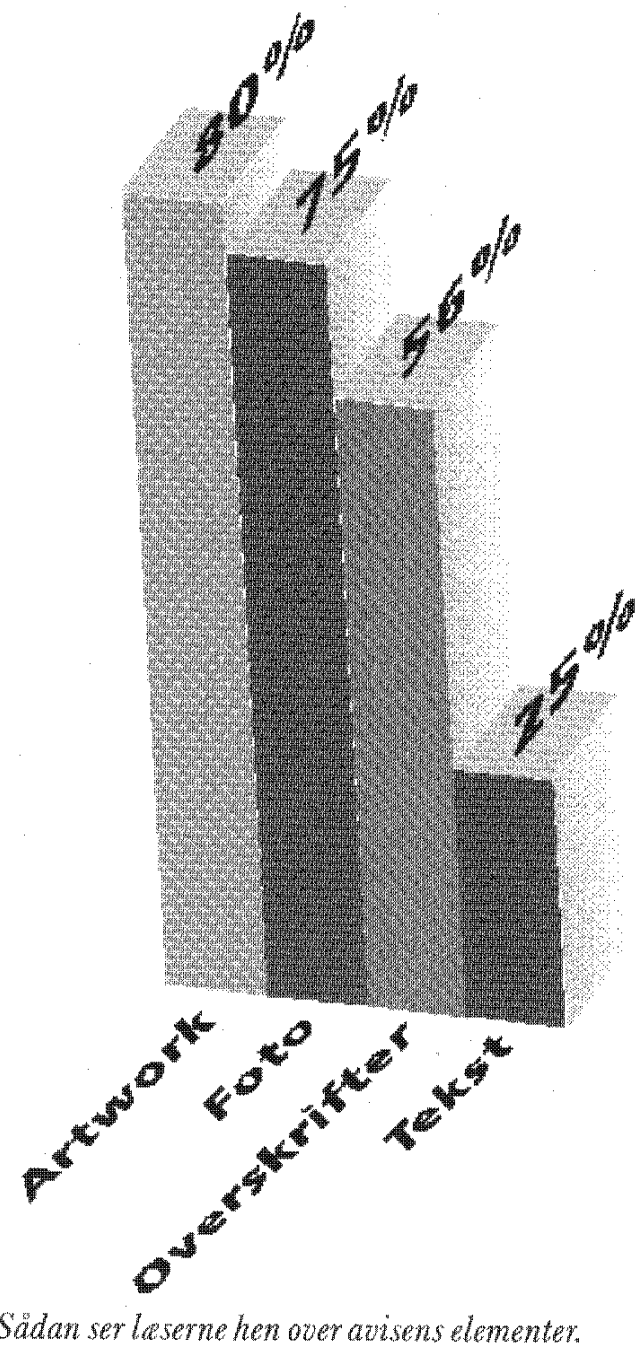


Eksperimenterne viste, at kun $25 \%$ af teksten bliver set-på, og kun halvdelen af den sete tekst bliver virkelig last grundigt.

Hvis laserne ikke læser teksten, hvad gør de så? De ser-på det visuelle. $80 \%$ af artworken, dvs. tegninger og nyhedsgrafik, bliver set-på. $75 \%$ af fotografierne bliver set-på, og store fotografier mere end sma - farvebilleder mere end sort/hvid fotografier. $56 \%$ af overskrifterne bliver set-på, og kun 25\% af teksten bliver set-på (Garcia 1991:6). Lidt mere end halvdelen af overskrifterne bliver set-på, men hvis der er et fotografi forbundet med overskriften, bliver den set-på af $72 \%$. Overskrifter og fotografier filtrerer laserens interesse til eller vak fra teksten, så selv om fotograficr tiltrækker opmerksomheden, cr de ingen garanti for at lxeseren vil se eller endda laese den medfolgende tekst.

Poynter Institutc konkluderer, at hvis alle lassere er scannere, er det klart, at de fleste aviser ikke er designet til at mode scannernes behov. Men design kan gøre forskellen:

„Vi må vak fra den omvendt pyramides tyranni, et gammelt og agtvaerdigt påfund som er kedelig, hvis det ikke direkte er destruktivt. »Hvis scannere treder ind i en historie hvor de nu tilfeldigvis er landet så må den tekst, som følger disse indgange have en ledende kvalitet. « En god pointe men det er ikke sådan de fleste historier bliver skrevet. Den omvendte pyramide har stadigvæk evnen til at vende op og ned på vore mulighed for at imodekomme scannerne." (Garcia 1991:45)

Disse eye-tracking undersogelser kan bidrage til at sandsynliggøre en af vore common sense forestillinger om avisen. Men den slags undersøgelser har også medvirket til, at designfirmaer og berømte designere har fàct et nyt grundlag for at skabe et anderledes avisdesign. Den amerikanske designer Garcia er en af guruerne, der rejser rundt og realiserer de tanker, der baserer sig på cye-tracking undersøgelserne. For den enkelte avis vil det ofte betyde at generelle og grundlaggende strukturelle forandringer planlagges og indfores ud fra denne slags overordnede principper. Det handler om i-side-sattelsen og hele det narrative forlob, som den daglige avis skal have, Et overordnet design går ogsa ind og fastlxgger typografi, brugen af fotografier pá siden eller pá opslaget med to sider over for hinanden. Desuden fastlagger et overordnet design nyhedsgrafikkens design og brug, brugen af alle de designelementer som står til ră- dighed, artiklemes struktur og indgange, opdeling af informationerne i tekst, billeder, nyhedsgrafik og tekstbokse. Det overordnede design kan altså gribe ind i både det astetiske men ogsă $\mathrm{i}$ indholdets tilrettelæggelse.

Man kan have den forestilling, at det stadigvaek er "virkeligheden", der afspejles i avisen, men gennem i-side-sattelsen griber det visuelle udtryk i stadig storre grad ind i "virkeligheden". På Fyens Stiftstidende er man nu igang med en teknisk omlagning, hvor man vil bruge et nyt redaktionelt computersystem, hvis primare opgave er at give mulighed for en endnu højere grad af kreativitet. Man vil vende den traditionelle arbejdsproces $180^{\circ} \ll$.

"De fleste dagblade laves med teksten som udgangspunkt. Vi vil meget gerne vare idé- og layoutdrevet, hwor vi via en dynamisk losning kan styre processen allerede for journalisterne begyn der at skrive. Vi vil kunne styre hvilke typer historier og hvor mange af slagsen der skal vare på siderne", siger systemchef Henning Sajbjcrg. ${ }^{8}$

Men selv inden den traditionelle arbejdsproces er vendt helt på hovedet, så har den teknologiske udvikling forandret avisens produktion og visuelle udtryk. 57-forsiden er et meget godt udtryk for, at hele avisen blev fremstillet i hojtryk og blev ombrudt $i$ handen af typografer. Fotografier skulle forst forvandles til klich ${ }^{3} \mathrm{er}$, for de kunne placeres sammen med tekstlinierne. Hvis man skulle foretage store andringer, skulle man forst have sat f.eks. en overskrift i bly, for den kunne placeres på siden. Det var en meget tung og langsom proces, og derefter blev avisen trykt i hojtryk i en kvalitet, som var temmelig ringe. Man trykte også udelukkende i sort/hvid med måske cn enkelt farve. Rigtige farvebilleder var det ikke muligt at trykke.

I dagens avis er produktionen forandret. Man trykker i offset, som giver mulighed for en højere kvalitet i tekst $o g$ billeder. Man trykker i rimelige farver og kan altsa nemt lave gode farvebilleder. Det betyder også, at alle pressefotos nu laves i farve som standard. Senere i processen kan man sa beslutte, om de skal reproduceres i sort/hvid.

Den vesentligste faktor er indforelsen af computere med indscanning af fotografier og med ombrydning i layoutprogrammer ved hjolp af en række forprogrammerede typografier og moduler. Man kan på fä minutter andre skriftstorrelse i overskrifter, ændre placeringen pä siden eller forstorre eller formindske et fotografi. Og hele ar- 
bejdsprocessen kan udføres enten af redaktøren selv, af journalisten eller af en layouter.

\section{Det tavse sprog}

Det er ikke alt i dagens avis, der er nyt. Derfor indtræeder visualiscringen og mediexstetiseringen af avisen som ct redskab til at få »gammelheder til at se nye ud. Aviserne indgår som varer og skal konkurrere om forbrugernes opmarksomhed. Derfor skal de samme nyheder kunne fremtrade som forskellige og mere vardifulde end konkurrentens. Derfor skal avisen også sxlge en mervardi, som giver den et image, hvorved den adskiller sig fra de andre aviser. Det ligger i forlængelse af de tanker, som Wolfgang Fritz Haug (1972) introducerede i halvfjerserne.

Det er her avislayouten indgår som en vigtig faktor. Kravet om originalitet oger kravet til egne og selvstrendige visualiseringer. Det kan enten opfyldes gennem billedvalg eller gennem den visuelle redigering.

Der er to modstridende tendenser. $\mathrm{Pa}$ den ene side en straben efter det unikke, det originale og det nye. Og på den anden side en stræben efter en organisering og en orden på virkelighedens kaos, som gor at fremstillingen ikke bliver for truende og ny. Derfor kan man se bestrabelseme på at skabe en fast struktur og en fast placering af bestemte stofområder som udtryk for forsøget på at sikre trygheden. Men samtidig skal det industrialiserede og rutinepragede nyhedsprodukt tilfojes noget nyt, og her er mediexstetikken et af svarene. Det estetiske forbinder sig med det kendte og kan tilfore noget, som er overraskende og fascinerende. Det er ikke tilfaldigt, at man kan finde lighedspunkter og fallestrak mellem avisernes annoncer og avisernes artikler og design. Det er reklamens astetik, som cr blevet en del af avisens astetik i forsøget på at fremstille en vare, som både er tryg og fascinerende.

Hvis vi accepterer at laserene er scannere, så spiller det visuelle udtryk en stor rolle il lasemes udvalgelsesproces og fokusering. I den industrialiserede avisproduktion indgår mange opdelte funktioner, og derfor vil der meget ofte være sprakker og modsigelser mellem det visuelle udtryk og artiklemes indhold. Hvis vi accepterer at det visuelle uditryk er overordnet teksten, kunne man forledes til at mene, at teksten ikke betyder noget. Men når laseren er scanner, så er det også udtryk for at dele af teksten scannes. Laseren behøver ikke at lase cn hel artikel for at fatte det nye den fortaller eller for at fa bekreftet det, laseren allerede ved. Avisens artikler indeholder sjweldent evighedens tekster men netop dagens tekster, og derfor kan man som laser hurtigt scanne dem.

Mediexstetikken er meget velegnet til at skabe en forestilling om nyhed og forskellighed. Analysen af mediexstetikken cr samtidig også en god måde at fă fat på det, som er avisens livsverden, avisens holdninger og avisens myter. Avisen indgår i en stadig og vedblivende konstruktion afverden. Avisens vigtigste funktion er at vise, at verden er til. Og gennem den stadige og fornyede fortalling af det gamle vedligeholdes fortallingerne. Det som ikke siges, bliver gjort usynligt. Det som siges, gares synligt. Det som også făr et visuelt udtryk forstarkes og gøres sardeles synligt.

Det synlige kan ikke ses bevidst. I den daglige avislasning er der ingen, der husker medieastetikken. Der er kun fä, der bruger mere end brøkdele af et sekund pa at se det mediexstetiske. Men det vi ikke ser, det ser vi alligevel. Det vi ikke lagger marke til, lagger vi alligevel marke til. Det der råber så højt, hører vi ikke bevidst. Men vi opfatter alligevel det vasentlige. Det tavse sprog forstär vi.

\section{Litteratur}

Barthes, Roland (1964): "Billedets retorik", in Visuel Kommunihation, Medusa 1980, side 42,57

Finberg, H.I. \& Itule, B.D. (1990).Visual Editing A Grabhic Guide for Jounalists, Belmont, Wadsworth Publishing Company

Garcia, M.T. \& Stark, P. (1991): Eyes on the New, St. Petersburg, The Poynter Institute.

Haug, Wolfgang Fritz (1972): "Kritik af vareastetikken", in Findrosen $1 \mathrm{r} .4 / 72$

Ingemann, Bruno (1989a): Tv-Avisen og Avisen presenterer: Billeder fra virkeligheden, Aschehoug

Ingemann, Bruno (1989b): Billedtor, RUC

Ingemann, Bruno (1991), Grafisk, Design-on dekrabive processer, strategier og deres resultat, Papirer i faglig formidling/Kommunikations Uddannelsen RUC $27 / 199$

Ingemann, Bruno (1996): Fotografiet under pres. Mellem realisme og honstnktion, Roskilde Universitetsforlag

Ingemann, Bruno (1998): FATAMORGANA. Pressefolografiets virkelighed og lesernes, Kobenhavn, Museum Tusculanums Forlag (udkommer i foră ret)

\section{Noter}

I Det behandler jeg ikke her. Men man kunne vare interesseret i det visuelle udtryks historic og se på udvalgte eksempler fra en bestemt avis, en bestemt. dag - over en 10-20-30ârs periode, man kan foku- 
sere pa ct bestemt emne eller begivenheds forskellige behandling i here aviser (Ingemann 1989:44); man kan sammenligne avisens representation med Tvravisens; man kan lave mere eksperimentelle forsog med det visuelle udtryk (Ingemann 1998). Men vigtigst af alt: formuler et godt problem.

2 Jeg har forste gang skrevet om denne analysestruktur i Ingemann: "Den glatte overflade" in Dansh Noter, nr. 1, 1994 p. 32-38. Signe Bonnén har brugt denne analysestruktur pa en konkret avisartikel i "Se det skel Det visuelle udtryk" in J Jorgensen, Keld Gall \& Geist, Uwe (red); Det nye kortog, Sproganalytshe vinkler pä en sagprosatekst, Roskilde Universitetsforlag 1996, p.33-47.

3 Jeg har tidligere behandlet pressefotografiet grundigt i Fotografiet under pres. Mellem realisme og kontwution (Ingemann 1996). Her har jeg ogsĭ presenteret min teori om lasernes lasestrategier. Dem har jeg udforsket eksperimentel i Fatamorgana - pressefotografotw virkelighed og lesemes (Ingemann 1998).

4. En god introduktion til forskellige mader at analysere avistekster på findes iJorgensen, Keld Gall \& Geist, Uwe (red.) Detnye horslog. Sproganalytiskevinkler pa en sagprosatekst, Roskilde Universitetsforlag 1996. Her findes et utal af litteraturhenvisninger. Sarlig interessant synes jeg er Jorgensen, Charlotte \& Onsberg, Merete Praktisk argumentation, Teknisk Forlag
1987; og Jensen, Leif Becker Tekstanalyse, RUC/Kommunikation 1985.

5 Man kan gå endnu mere detaljeret til vaerks när det galder analysen af Helhedsbilledet. Man kan se narmere pá astetiske virkemidler som farve, lys skygge, streger, tekstur, kontraster, rum, synsvinkel, perspektiv. Man kan prøve at fastlagge ojets bevagelser hen over siden: hvor fanges ojet og hvor vandrer det derefter hen... for det er grundleggende den funktion som kompositionen har.

6 Det gennemgående elsempel jeg bruger her bliver ikke analyseret til bunds. Jeg nojes med at skitsere nogle muligheder og pointer som jeg kan bruge til at udvikle og prasentere teori og metode.

7 Hvortor har han ikke valgt formiddagsbladene? For de er jo endmu voldsommere i deres visuelle udtryk. Man kunne ogsa valge at bruge Sondagsaviserne som indeholder mange endnu mere udfolde visuelle udtryk. Det er netop derfor: de er så indlysende at det for mig er mere interessant at fokusere på en ganske almindelig avis.

8. DTP. Grafishe Medier nr.10, 1997 p. 2.

Bruno Ingemann er lektor ved Kommunikationsuddannelsen, Roskilde Universitetscenter 